\title{
Evaluation of Chemistry Learning Programs at Vocational High School Semarang on Vehicle Engineering Field
}

\author{
Roudloh Muna Lia ${ }^{1}$, Wiwi Isnaeni ${ }^{2}$ \\ ${ }^{1,2}$ Research and Educational Evaluation, Graduate School, Unversitas Negeri Semarang, Indonesia \\ ${ }^{1}$ Corresponding email: muna@gmail.com
}

\begin{abstract}
Low interest in Vocational High School students to study chemistry need to be evaluated. This study aims to evaluate the quality of the learning process chemistry by analysing learning process and teachers' ability in teaching; identifying the interests of learners, and analysing the quality of the learning process and the quality of chemistry test. The sample of this research is the students of X, XI, and XII classes at a Vocational School in Semarang on Vehicle Engineering Field/ TKR, 162 people. This research used the discrepancy models. Data collection: observation, interview and documentation. The Data were analysed qualitatively and quantitatively using the classical test theory and Item Response Theory Model Rasch 1 PL. The results were: (1) slightly the learners who achieve a level of mastery learning. (2) the teacher has yet to implement a scientific approach. (3) the cause of the low learning items were (a) learners less practice working on the question, (b) consider learners chemical unimportant subjects (not relevant to the field of intense). (4) the majority of the students of class XII worked on the final examination with cheating, and one-third of the students they would answer a question of chemistry with guessing.
\end{abstract}

Keywords: Evaluation of Chemical Learning Program, the Discrepancy Model.

\section{Introduction}

Vehicle Engineering Field (TKR in Bahasa Indonesia) is one of a vocational skills program in Semarang. Vocational education tend to require graduates ready to work (Velde, 2009; De Bruijn, 2011). The use of a learning system that is incompatible with the interests of learners caused low learning achievement. The material in Vocational High School (VHS) is divided into two, the material productive and non-productive. The learning achievement in VHS is low, especially for not productive materials, such as chemistry's subjects. In the curriculum of 2013, the chemistry in vocational belongs to a group of specialization/ C1 (Haryanti \& Antuni Wiyarsi, 2017). Boddey and Berg (2015) explain that the vocational school learners who have low achievement tend to think of chemistry's subjects not relevant to the vocational fields that have an impact on the interest students is low.

Chemistry daily assessment, Midterm examination and Final examination program on Skills TKR at a vocational school in Semarang indicate that all learners did not get the Minimum Completeness Criteria. These

factors, there are also external factors that affect the interests of learners environmental factors i.e. home, school, and community.

Another factor that needs to be analysed is the teacher readiness factors. Teachers must be evaluation learning program themselves by circumstances indicate that the learning process has not been as expected. The discrepancy between expectations and reality, motivating to analysing and evaluating by analysing and evaluation of learning program chemical processes and learning outcomes.

The results of the questionnaire and field observations indicate the teachers in teaching still as unidirectional communication. Based on the results of questionnaires given to students TKR class showed that as many as $76 \%$ of students stated that chemistry is a difficult subjects, and $64 \%$ of students expressed dislike the chemistry lesson. (The questionnaire results November 2017). It indicates that the interest of students to participate in learning chemistry is low.

Low interest of students to study chemistry caused by various factors. Numerous studies showed that these factors include personal factors, attitudes toward science, and the type of school (Akram, et al., 2017). Interest in learning chemistry is the internal factors that didn't reach learning goals chemistry. (Rusman, 2017). In addition to internal

asking learners to observe their lessons teachers. Things that need to be observed among others teacher's communication ability in explaining and spirit of students in participating in learning. From the description can be affirmed that evaluation learning 
program needs to be done in various ways, to know several things such as the quality of the learning process and learning outcomes of students. According to Worthen in Isnaeni, W. (2015), evaluation program may be an attempt to fix the parts of the program implementation is still far from perfect. Without evaluation, a program cannot be monitored.

Referring to the descriptions above, in order to overcome the problems of chemical processes and learning outcomes in a vocational school in Semarang, need to be analysed factors affecting learning at the school. In this study, evaluation of chemistry learning programs are analysing learning process and a chemistry teacher teaching ability; identifying the interests of learners, and analysing the quality of chemistry uses classical test theory and Item Response Theory Model Rasch 1 PL.

Classical test theory has been used to determine the level of difficulty and other characteristics of a measuring instrument, but it still has shortcomings. (Nahadi, 2011). The shortcomings related to the method of determining the score. Scores level of difficulty and distinguishing features about the results of the analysis depends on the number of test takers (Baylari \& Montazer, 2009). To overcome the shortcomings of the classical test theory, need to do the analysis using Item Response Theory (IRT). Hambleton et al.
(1991) suggested the item response theory (IRT) is a theory which states that the test results can be predicted or explained through a series of so-called trait factors, latent trait or abilities. The higher level of ability testee, the greater the chance the testee answered correctly an item. Thus we can say that the classical test theory is "test based" while the IRT an "itembased".

\section{Methods}

The design used in this evaluation program using a combination of quantitative and qualitative (mixed method) with Sequential models Explanatory Design (Sugiyono, 2011). The research model evaluation learning program used to use discrepency models (Buttram, 1978; Isnaeni, 2015).

These methods mix method is used to describe, analyse and formulate: (1) Learning Process and a Chemistry Teacher Teaching Ability, (2) Interests of Students in Chemistry Lesson (3) The analysis quality of chemistry test. Points Research study was conducted at a vocational school in Semarang in the academic year 2017/2018. Samples were all students of class X, XI, and XII classes at a vocational school in Semarang, 162 students. This type of data, the categories of data, the instrument used, data collection techniques, and data sources are presented in Table 1.

Table 1. Type and Category Data, Instrument, Engineering Data Collection and Data Sources on Research

\begin{tabular}{cllll} 
No & \multicolumn{1}{c}{$\begin{array}{c}\text { Types and } \\
\text { categories of data }\end{array}$} & $\begin{array}{c}\text { Techniques and } \\
\text { methods of data } \\
\text { collection }\end{array}$ & Instrument & Data source \\
\hline $1 \quad \begin{array}{l}\text { Learning Process and a } \\
\text { Chemistry Teacher } \\
\text { Teaching Ability }\end{array}$ & $\begin{array}{l}\text { Categorization Field Notes } \\
\text { (Quantitative) }\end{array}$ & Categorization sheet & Field notes \\
2 & $\begin{array}{l}\text { Interests of Students in } \\
\text { Chemistry Lesson }\end{array}$ & $\begin{array}{l}\text { questionnaires; Interview } \\
\text { (Qualitative) }\end{array}$ & questionnaires; Free Interview & Students Program TKR \\
3 & $\begin{array}{l}\text { The analysis quality of } \\
\text { chemistry test }\end{array}$ & $\begin{array}{l}\text { Documentation } \\
\text { (Quantitative described) }\end{array}$ & $\begin{array}{l}\text { Questions + Answers Document } \\
\text { Sheet of Midterm Examination, } \\
\text { Final Examination and Chemistry } \\
\text { Daily Assessment ; questionnaires }\end{array}$ & $\begin{array}{l}\text { Questions + Answers } \\
\text { and Final Examination } \\
\text { of Chemistry }\end{array}$
\end{tabular}




\section{Results and Discussion}

\subsection{Learning Process Analysis and Chemistry Teacher Teaching Ability.}

Based on the analysis of chemistry teachers in the learning process, the students still need to be guided when practicing work on the problems. Manning, S., (2010) states was still directed learners teachers indicate such learners still need guidance in order to draft the Final examination be intact. Most learners have not possess basic mathematical concepts were applied in calculations of chemistry. When compared to the material productive learners prefer lessons productive than chemical. This is in accordance with the opinion of Boddey \& Berg (2015), which explains that the students of vocational schools have a generally low achievement because it tends to look at the chemistry was not relevant to the vocational fields that have an impact on the low value of the chemistry. Velde (2009) also confirms that vocational education graduates tend to require working directly.

In this research observation of when teachers teach. Figure 1 presents an analysis of the ability of teachers to teach chemistry. There are six aspects and each aspect are translated into a number of indicators. The sixth aspect is (1) Skills opening the lesson, (2) Skills explained, (3) use of instructional media, (4) The application of learning methods, (5) Skills assessment and learning process, (6) closes Skills lesson.

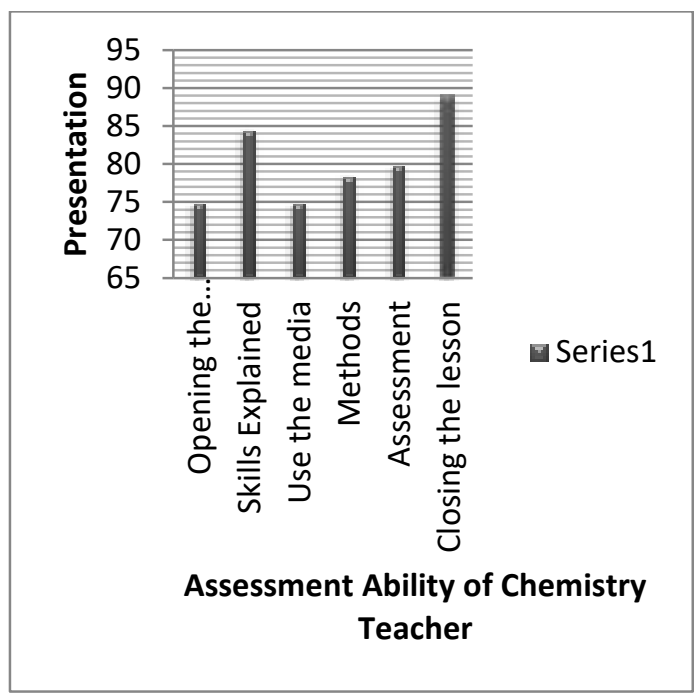

Figure 1. Results of the Quantitative Findings

In Figure 1, we can see that the largest percentage contained on closing skills subjects
(89\%) and skills to explain (84.5\%). They need to be explained and elaborated using qualitative data in the form of field notes. Based on field notes by the observer can be obtained information that teachers act as a resource and as a facilitator. At the time of chromatography lab demonstrations in class XII, teachers brought all lab equipment. By the time the lab, the students simply observing and not involved in the measure, classify, and conclude. That is yet to implement learning activities Process Skills Approach. Approach Process Skills in basic skills by Atmojo (2012) includes the skills of observation, classification, communication, measurement, estimation, prediction and interference. The use of process skills are not exhaustive allegedly would affect the ability of learners in generating new knowledge.

3.2 Interests of Students in Chemistry lesson.

Results of the questionnaire showed that $76 \%$ of students stated that it was difficult chemical subjects. They said, amounted to $61.54 \%$ lies the difficulty lies in the formula of molecular / ion, and $3.85 \%$ said it was difficult on how to calculate it, as well as the mixing of substances. When working on the problems with complex material, learners are not able to apply the formula/ basic concept in question is concerned. That is because the learners do not repeat the lessons at home. A total of $48 \%$ of learners TKR also assume that the chemical subjects that did not matter. Based on these descriptions, internal factors are the cause of not achieving the learning objectives are still relatively low. The cause is a lack learners have an interest in chemistry and assume that the chemical material is not important.

3.3 The analysis quality of chemistry test.

Analysis quality of chemistry test in classical theory test are measure the item validity, reliability, item difficulty, and discrimination indices of chemistry test. The results show that Mid-Term and Final examination largely invalid, while the reliability test Final examination Class X TKR, TKR XI, and XII respectively TKR 0.95 ; 0.93 ; and 0.94 . It shows that the chemistry problem has a very high confidence level because, according to Fornel, C., \& Larcker, D. F. (1981) in Hung (2010) have value if the reliability 0,7 is an acceptable value and can be stated as well that the achievement test that already have good quality (Sudijono, 2015:207). 
For the item difficulty test with medium and difficult category. Item is still small. Good items are moderate, and the distribution between those three categories proportional (Nur Hasanah, 2017). Then, the discrimination indices items on the final examination is ugly. Therefore, it can be concluded that the problem device has not been able to distinguish between learners master the competencies with learners who are less competence (Mitra, 2009).

Based on Item Response Theory on Winsteps program obtained information that as many as $33.5 \%$ of students who indicated answered questions with guesses seen from Scalogram on Rasch analysis 1 PL and the total of $96 \%$ of students of class XII TKR indicated cheating when doing chemistry test. Regarding the item fit, there is one item on the Middle examination X TKR and 4 items on the Final Assessment semester's class XII TKR must be replaced because it does not meet the criteria of the value of the items fit.

On the classical theory test a device about the Final examination on the class $\mathrm{X}$ and $\mathrm{XI}$ TKR TKR cannot be used because it does not meet the validity criteria. However, when tested with the Item Response Theory, the results showed that the number of items on the Middle examination X TKR to be discarded was only one item. This proves that the test results to the raw score on classical test theory always depend on the number of test takers. The cause of the problem becomes invalid is because 29\% of learners answer questions by guessing.

In addition to a review of the Mid-term examination and Final examination, the analysis were also performed on a daily assessment, by measure the achievement of competence quintessentially. Regarding the achievement of basic competencies (BC), class $\mathrm{X}$ is smallest achievement of the average, was $36.92 \%$. The cause is the learners are not ready to accept the lesson, and his thoughts are not focused on lessons. Hao (2016) states that class more effective if learners have self-directed readiness. Learners are not ready to receive the material provided by the teacher caused accepting new concepts are not optimal.

\section{Conclusion}

In Vehicle Engineering Field very little programming skills of learners who achieve the level of mastery learning. The quality of teaching teachers as a resource and facilitator yet to implement Process Skills Approach.
Found some of the causes of low student learning outcomes, namely:

Learners less practice work on the problems.

Vocational school learners assume no chemical subject matter (not relevant to the occupied areas).

Most of the students of class XII in doing item about Final examination indicated cheating, and one-third of students indicated TKR membership program answered the item chemistry with guesses. The conclusion that the quality of the learning process in a vocational school in Semarang is not optimal.

\section{References}

Akram, T.M., Ijaz, A., \& Ikram, H. (2017). Exploring the factors responsible for Declining Students' Interest in Chemistry, International Journal of Information and Education Technology, 7(2).

Atmojo, S. E. (2012). Profil Keterampilan Proses Sains dan Apresiasi Siswa Terhadap Profesi Pengrajin Tempe dalam Pembelajaran IPA Berpendekatan Etnosains. Jurnal Pendidikan IPA UNNES Indonesia, 1(2).

Manning, S., Stanford, B. P., \& Reeves, S. (2010). Valuing the advanced learner: Differentiating up. The Clearing House, 83(4), 145-149.

Baylari, A. and Montazer. (2009). Design A Personalized E-Learning System Based On Item Response Theory and Artificial Neural Network Approach. Elsevier. 36 (8013-8021).

Buttram, Joan L. (1978). The Discrepency Evaluation Model : A Systematic Approach for The Evaluation of Career Planning and Placement Programs. Washington : ERIC Clearinghouse.

Boddey, K. \& Berg, K.d. (2015). The impact of nursing students' prior chemistry experience on academic performance and perception of relevance in a health science course, Chemistry Education Research and Practice, 16.

Hambleton R.K, Swaminathan, H dan Rogers, H.J. 1991. Fundamentals of Item Response Theory. California: Sage Publications,Inc.

Hao, Y. (2016).Exploring Undergraduates' Perspectives and flipped learning readiness in their flipped classrooms. Computers in Human Behavior.2016, 59, 
$82-92$.

Hasanah, Nur dan Herlina Ahmad, 2017. Analisis Soal Ujian Tengah Semester (UTS) Mata Kuliah Geometri, Jurnal Pendidikan Pepatudzu. 2 (1).

Hung, M. L., Chou, C., Chen, C. H., \& Own, Z. Y. (2010). Learner readiness for online learning: Scale development and student perceptions. Computers Education, 55(3), 1080-1090

Isnaeni, Wiwi. (2015). Evaluasi Implementasi PKP Dalam Pembelajaran Biologi Di SMAN Kota Semarang Menggunakan Pendekatan Mixed-Method. Jurnal Penelitian dan Evaluasi Pendidikan, 19 (1), 109-121.

Mitra, N. K., Nagaraja, H. S., Ponnudurai, G., \& Judson, J. P. (2009). The levels of difficulty and discrimination indices in type a multiple choice questions of preclinical semester 1, multidisciplinary summative tests. IeJSME, 3(1), 2-7.

Nahadi, et al. (2011), Pengembangan Dan Analisis Soal Ulangan Kenaikan Kelas Kimia SMA Kelas X Berdasarkan Classical Test Theory dan Item Response Theory, Jurnal Pengajaran MIPA 16 (2).
Rusman, (2017). Belajar dan Pembalajaran Berorientasi Standar Proses Pendidikan. Jakarta : Kencana.

Santoso, Y. (2013). Analisis Butir Soal Ujian Tengah Semester Ganjil Mata Diklat Teori Produktif Untuk Siswa Kelas X SMK Muhammadiyah 1 Bantul 2012/2013. Skripsi. Yogyakarta : Program Studi Pendidikan Teknik Mesin Fakultas Teknik UNY.

Sudijono, Anas. (2015). Pengantar Evaluasi Pendidikan. Jakarta : Rajawali Pers.

Sugiyono, (2016). Metode Penelitian Kombinasi (Mixed Methods). Bandung : Alfabeta.

Sumintono, Bambang dan Wahyu Widhiarso. (2015). Aplikasi Pemodelan Rasch : pada Assessment Pendidikan. Cimahi : Trim Komunikata.

The Result of questionnaire on TKR Program (November 2017).

Velde, C. (2009). Employers' perceptions of graduate competencies and future trends in higher vocational education in China. Journal of Vocational Education and Training, 61(1), 35-51. 